\title{
LAYANAN APLIKASI GO-JEK: VALIDASI SKALA PENGUKURAN IRSQ PERSEPSI KONSUMEN PADA PENGGUNAAN PLATFORM GO-FOOD
}

\author{
Ika Barokah Suryaningsih \\ Fakultas Ekonomi dan Bisnis, Universitas Jember, Jawa Timur
}

\begin{abstract}
Abstrak $\mid$ Penelitian ini bertujuan untuk menganalisis faktor-faktor yang membentuk persepsi konsumen dalam menggunakan aplikasi Go-jek, khususnya untuk platform Go-food di Kota Jember, dengan mengadopsi skala pengukuran Internet Retail Service Quality (IRSQ). Atribut yang diuji berjumlah 20 atribut yang dianalisis menggunakan Exploratory Factor Analysis (EFA). Populasi penelitian ini adalah masyarakat Kota Jember yang menggunakan platform Go-food dalam aplikasi Go-jek. Metode pengambilan sampel yang digunakan adalah purposive sampling dengan jumlah sampel sebanyak 140 responden. Hasil penelitian menunjukkan bahwa terdapat 5 faktor yang menentukan persepsi konsumen dalam menggunakan platform Go-Food. Faktor yang paling dominan adalah adalah kinerja layanan yang terdiri dari atribut pesanan online mudah dipahami, pesan konfirmasi pesanan cepat, loading time yang cepat, pemrosesan pesanan bebas kesalahan, pengiriman pesanan cepat, dan kebijakan return pesanan. Faktor kedua adalah kemudahan akses yang terdiri dari atribut tawaran beragam produk mitra, tawaran produk promosi, rekomendasi produk lain yang unik, dan dukungan berbagai cara pembayaran. Faktor ketiga adalah interaksi yang terdiri dari atribut ketersediaan chatroom online, ketersediaan gambar produk, dan interaksi komunikasi. Faktor keempat adalah informasi yang terdiri dari atribut informasi ketersediaan produk dan informasi yang disediakan akurat, sedangkan faktor kelima adalah keamanan yang terdiri dari atribut informasi pribadi dan informasi akun yang aman.
\end{abstract}

Kata Kunci: Go-jek, Go-food, IRSQ, layanan, persepsi konsumen

\begin{abstract}
This study aims to analyze the factors forming consumers' perceptions in using the Go-food platform at Go-jek application by adopting an IRSQ measurement scale. This study examined 20 attributes of IRSQ that were analyzed using EFA. The population of this study was the citizens of Jember who have used the Go-food platform at Go-jek application. The sample consisted of 140 respondents collected by employing a purposive sampling technique. The results showed that there were 5 factors forming consumers' perceptions of using the Go-Food platform. The most dominant factor was services performance consisting of the attributes of easy-to-understand online order, fast order confirmation messages, fast loading time, error-free order processing, fast order delivery, and order return policies. The second factor was ease of access consisting of the attributes of various products offering by Go-jek's partners, promotional products offer, recommendations for the unique products, and various payment methods. The third factor was interaction consisting of the attributes of online chatrooms, product images, and communication interactions. The fourth factor was information that consists of the attributes of product availability information and accuracy of the information, while the fifth factor was security that consists of the attributes of personal information and secure account information.
\end{abstract}

Keywords: consumer perception, Go-jek, Go-food, IRSQ, services

Fakultas Ekonomi dan Bisnis Universitas Jember

Jl. Kalimantan 37 Tegal Boto Jember

E-mail: barokah.feb@unej.ac.id 


\section{Pendahuluan}

Perkembangan teknologi informasi dan komunikasi berkembang pesat, termasuk jasa layanan tranportasi online, saat ini banyak bermunculan jasa transportasi online di Indonesia seperti GO-JEK, grabbike, grabtaxi, uber dan lain-lain. Ojek online adalah sebuah transportasi umum yang menggunakan aplikasi dan jaringan internet untuk memesannya. Aplikasi tersebut berbasis android sehingga dapat digunakan kapan saja dan dimana saja. Dengan menggunakan aplikasi akan memudahkan pelanggan dalam pemesanan dan akan memudahkan penyedia layanan jika ada pesanan ojek. Menurut Kotler (2000: 224) perilaku konsumen secara umum dipengaruhi oleh empat faktor yaitu budaya (budaya, sub budaya dan kelas sosial), sosial (kelompok acuan, keluarga, serta peran dan status), pribadi (usia, pendapatan, pekerjaan, gaya hidup, kepribadian dan konsep diri), dan psikologis (motivasi, persepsi, pengetahuan, keyakinan dan sikap) dimana faktor-faktor ini bisa secara individu atau bersama dapat memengaruhi keputusan seseorang untuk melakukan pembelian baik memilih produk atau jasa, memilih jenis, penentuan saat pembelian maupun tempat dimana harus membeli khususnya melalui pembelian online (Ardyanto,2015).

Gojek adalah perusahaan dengan total transportasi terbesar di Indonesia dari hasil riset "Lembaga Riset Global" (GFK) total keseluruhan dari pengguna aplikasi Gojek hingga sekarang ini mecapai $21,6 \%$ dari jumlah semua total pengguna aplikasi teknologi di Indonesia. Dan perusahaan Grab sebesar 6,4\% untuk apps transportasi Gojek yang paling banyak digunakan, dan selanjutnya perusahaan Grab dan Kereta Api Indonesia, JNE, serta Uber menurut peneliti GFK Robin (http://m.okezone.com, 2018)

Dari Data TBI Merek Jasa Transportasi Online yang tertinggi adalah merek Gojek dengan jumlah $80,6 \%$, yang diikuti oleh Grab sebesar $14,7 \%$, dan selajutnya Uber sebesar $1,7 \%$ dan Blue-Jek sebesar 0,7\% (www.topbrand.com, 2018). semakin tinggi nilai presentasi TBI-nya maka brand akan semakin kuat didalam benak konsumen. Gojek merupakan salah satu penyedia layanan jasa transportasi online khususnya sepeda motor. Gojek adalah perusahaan berjiwa sosial yang memimpin revolusi industri transportasi ojek. Gojek menjadi salah satu solusi utama dalam pengiriman barang, pesan antar makanan, berbelanja dan berpergian ditengah kemacetan. Aplikasi gojek dapat diunduh pada smartphone yang memiliki IOS dan Android. Gojek memanfaatkan media elektronik sehingga akses untuk pemesanan jasa ojek lebih muda bagi konsumen. Aplikasi di smartphone kemudian gojek akan menjemput konsumen dan menggantar pelanggan sampai pada tempat tujuannya. Tidak hanya untuk antar jemput, gojek juga menyediakan layanan GO-FOOD yang dapat menjeput makanan favorite anda dari mana saja sesuai dengan yang anda pesan, GO-MART adalah salah satu layanan gojek yang siap membelanjakan kebutuhan anda dan masih banyak lagi fiturfitur yang diberikan oleh gojek.

Keberadaan aplikasi di Indonesia yang kemudian menjadi trend yaitu tranportasi berbasis aplikasi yang dilirik sebagai model $e$ commerce dikarenakan transportasi sendiri merupakan hal yang dasar untuk kehidupan manusia dalam melakukan perpindahan dari suatu tempat ke tempat lain. Salah satu transportasi berbasis aplikasi yang ada di Indonesia yaitu Gojek. Masyarakat mulai tertarik menggunakan aplikasi Gojek untuk memenuhi kebutuhan. Keberadaan aplikasi Gojek menempati posisi pertama sebagai "Mobile App Ranking" dengan kategori transportasi di Indonesia. Gojek juga mengalahkan posisi transportasi berbasis aplikasi lainnya seperti Grab Taxi dan Uber. Fenomena yang dapat dilihat adalah masyarakat mulai melibatkan keberadaan internet sebagai kebutuhan untuk perjalanan termasuk mencari informasi dan transportasi.

Gojek sebagai penyedia transportasi online berbasis aplikasi selain menyediakan jasa transportasi juga menyediakan berbagai jasa layanan lainnya seperti go-food, go-bluebird, go-mart, go-send, go-shop, dan masih banyak layanan lainnya (https://www.gojek.com/ 2019). harus mengetahui faktor-faktor apa saja yang berpengaruh secara nyata terhadap perilaku konsumen dalam pengambilan keputusan menggunakan jasanya (Mujiyana dan Ingge, 2013). Hal ini sangat bermanfaat bagi perusahaan agar dapat mengantisipasi hal-hal yang perlu dilakukan guna untuk 
mempertahankan kepercayaan konsumen dan meraih pangsa pasar (Verina, et al, 2014).

Platform yang paling banyak digunakan dalam aplikasi Gojek adalah Go-food dan Go-Pay (Novianty, dan Muslimin, 2019). Hasil Riset Lembaga Demografi Fakultas Ekonomi dan Bisnis Universitas Indonesia (LD FEB UI), Gofood menjadi layanan yang paling banyak diminati pada aplikasi Go-jek setelah Go-ride dan Go-car (Bayu, 2018). Go-food, saat ini tidak lagi menjadi gaya hidup kaum muda (Nurbayti, 2019), namun demikian sudah menjadi kebutuhan keluarga dalam memenuhi kebutuhan akan berbagai menu makanan yang bias langsung diantar pada alamat pemesan. Hal inilah yang menjadi customer value bagi layanan Go-food, dengan demikian konsumen dapat mengukur kualitas jasa berdasarkan insiden spesifik maupun secara general (TJiptono, 2014:308). Secara teori, kerangka konseptual terjadinya fenomena ini adalah terletak pada pengukuran kualitas jasa. Pengukuran kualitas layanan jasa khusunya online banyak terjadi kontradiksi (Tjiptono, 2014:298), sehinga terjadi dua perpektif besar yaitu Nordic dan SERVQUAL (Brady dan Cronin, 2001). Dilandasi fenomena dan konseptualisasi kualitas layanan jasa dalam konteks ritel internet terkait $e$-service quality maka penelitian penelitian ini menguji hasil identifikasi kualitas jasa ritel internet yang dikemukakan oleh Janda et al. (2002) yang disebut Internet Retail Service Quality (IRSQ) dengan jumlah atribut yang divalidasi sebanyak 20 atribut.

\section{Metodologi}

Menurut Sugiyono (2015:79), populasi merujuk pada sekumpulan orang atau objek yang memiliki kesamaan dalam satu atau beberapa hal yang membentuk masalah pokok suatu riset khusus. Populasi penelitian ini adalah masyarakat yang menggunakan Aplikasi Gojek melalui Platform Go-food. Metode pengambilan sampel pada penelitian ini menggunakan teknik nonprobability sampling yaitu dengan purposive sampling, sampel diambil dengan tujuan tertentu, anggota sampel dipilih sedemikian rupa agar sampel tersebut dapat mewakili sifat populasi. Sampel yang digunakan dalam penelitian sejumlah 140 responden yang memiliki kriteria, yaitu responden berusia 17 tahun ke atas dimana usia ini diasumsikan responden sudah cukup dewasa dan mengerti serta dapat menanggapi masing-masing pertanyaan dalam kuisioner penelitian dengan baik, dan responden merupakan pengambil keputusan dan pengguna Platform Go-Food. Alat analisis yang digunakan dalam penelitian ini adalah Exploratory Factor Analysis (EFA) yaitu proses untuk meringkas sejumlah atribut menjadi lebih sedikit dan menamakannya sebagai faktor (Ghozali, 2005:251).

\section{Hasil dan Pembahasan}

Hasil penelitian ini menunjukkan nilai ChiSquare adalah 1.000.903, dan memiliki probabilitas signifikansi 0,000. Dengan demikian, antar atribut-atribut yang dianalisis terdapat korelasi. Simamora (2005:123) mengemukakan bahwa $K M O$ adalah uji yang nilainya berkisar antara 0 sampai 1 , hal ini menujukkan kelayakan (appropriatness) dari analisis faktor. Lebih lanjut dijelaskan apabila nilai indeks tinggi (berkisar antara 0,5 sampai1,0), analisis faktor layak dilakukan. Sebaliknya, kalau nilai KMO di bawah 0,5 analisis faktor tidak layak dilakukan. Dalam penelitian ini, nilai $K M O$ sebesar 0,785 (berkisar 0,5 sampai 1,0), maka dapat disimpulkan bahwa analisis faktor layak dilakukan.

Angka-angka dalam matriks ini menyatakan korelasi parsial antaratribut, yaitu korelasi yang tidak dipengaruhi oleh atribut lain (Simamora, 2005:124). Pada tabel Anti-Image Correlation (bagian bawah tabel Anti-Image Matrices), terdapat sejumlah angka yang membentuk diagonal, yang bertanda "a". Tanda "a" ini menunjukkan besaran Measure of Sampling Adequacy (MSA) sebuah atribut. Angka $M S A$ ini berkisar 0 sampai 1, dengan kriteria (Santoso, 2001:101). Dalam penelitian ini, semua atribut memiliki nilai $M S A>0,5$. Jadi dapat dikatakan bahwa semua atribut bisa diproses lebih lanjut. Berikut disajikan pada Tabel 1 di bawah ini mengenai Anti-Image Correlation. 
Tabel 1. Nilai Korelasi Measure of Sampling Adequacy (MSA)

\begin{tabular}{|c|c|c|c|}
\hline Atribut & $\begin{array}{c}\text { Angka } \\
\text { MSA }\end{array}$ & $\begin{array}{c}\text { Kriteria } \\
\text { MSA }\end{array}$ & Keterangan \\
\hline $\begin{array}{l}\text { Menyediakan } \\
\text { Gambar produk }\end{array}$ & 0.734 & $>0,5$ & Layak \\
\hline $\begin{array}{l}\text { Menyediakan } \\
\text { Chatroom online }\end{array}$ & 0.644 & $>0,5$ & Layak \\
\hline $\begin{array}{l}\text { Pengiriman pesanan } \\
\text { cepat }\end{array}$ & 0.635 & $>0,5$ & Layak \\
\hline $\begin{array}{l}\text { Menyediakan } \\
\text { informasi produk } \\
\text { secara detail }\end{array}$ & 0.499 & $<0,5$ & Tidak Layak \\
\hline $\begin{array}{l}\text { Interaksi } \\
\text { Komunikasi yang } \\
\text { bagus }\end{array}$ & 0.851 & $>0,5$ & Layak \\
\hline $\begin{array}{l}\text { Kebijakan Retur } \\
\text { pesanan }\end{array}$ & 0.820 & $>0,5$ & Layak \\
\hline $\begin{array}{l}\text { Informasi } \\
\text { ketersediaan Produk }\end{array}$ & 0.803 & $>0,5$ & Layak \\
\hline $\begin{array}{l}\text { Merekomendasikan } \\
\text { Produk lain yang } \\
\text { unik }\end{array}$ & 0.866 & $>0,5$ & Layak \\
\hline $\begin{array}{l}\text { Fasilitas } \\
\text { PilihanProduk yang } \\
\text { direkomendasi }\end{array}$ & 0.478 & $<0,5$ & Tidak Layak \\
\hline $\begin{array}{l}\text { Menyediakan } \\
\text { informasi mitra yang } \\
\text { bagus }\end{array}$ & 0.489 & $<0,5$ & Tidak Layak \\
\hline $\begin{array}{l}\text { Menawarkan Produk } \\
\text { Promosi }\end{array}$ & 0.824 & $>0,5$ & Layak \\
\hline $\begin{array}{l}\text { Informasi yang } \\
\text { disediakan akurat }\end{array}$ & 0.777 & $>0,5$ & Layak \\
\hline $\begin{array}{l}\text { Menawarkan } \\
\text { beragam produk } \\
\text { Mitra }\end{array}$ & 0.749 & $>0,5$ & Layak \\
\hline $\begin{array}{l}\text { Pemrosesan pesanan } \\
\text { bebas kesalahan }\end{array}$ & 0.817 & $>0,5$ & Layak \\
\hline $\begin{array}{l}\text { Pesan konfirmasi } \\
\text { pesanan cepat }\end{array}$ & 0.763 & $>0,5$ & Layak \\
\hline $\begin{array}{l}\text { Meyakinkan } \\
\text { informasi pribadi } \\
\text { saya aman }\end{array}$ & 0.725 & $>0,5$ & Layak \\
\hline $\begin{array}{l}\text { Loading time yang } \\
\text { cepat }\end{array}$ & 0.782 & $>0,5$ & Layak \\
\hline $\begin{array}{l}\text { Pesanan online } \\
\text { mudah dipahami }\end{array}$ & 0.893 & $>0,5$ & Layak \\
\hline $\begin{array}{l}\text { Memiliki dukungan } \\
\text { berbagai cara } \\
\text { pembayaran }\end{array}$ & 0.759 & $>0,5$ & Layak \\
\hline $\begin{array}{l}\text { Meyakinkan bahwa } \\
\text { informasi akun aman }\end{array}$ & 0.699 & $>0,5$ & Layak \\
\hline
\end{tabular}

Sumber : data diolah, 2019
Penentuan jumlah faktor dalam penelitian ini didasarkan pada nilai Eigenvalue. Faktor yang nilai Eigenvalue-nya satu atau lebih besar dianggap valid. Sedangkan faktor yang nilai Eigenvalue-nya kurang dari satu dianggap tidak valid. berikut disajikan nilai Eigenvalue masing-masing faktor yang terbentuk. Berikut disajikan pada Tabel 2 di bawah ini mengenai penentuan jumlah faktor berdasarkan nilai Eigenvalue.

\section{Tabel 2. Total Variance Explained}

\begin{tabular}{cccc}
\hline \multirow{2}{*}{ Component } & \multicolumn{2}{c}{ Extraction Sums of Squared Loadings } \\
\%o of \\
Total & $\begin{array}{c}\text { Variance } \\
\text { Cumulative } \\
\text { \% }\end{array}$ \\
\hline 1 & 5.911 & 29.557 & 29.557 \\
2 & 2.893 & 14.463 & 44.020 \\
3 & 1.655 & 8.275 & 52.295 \\
4 & 1.307 & 6.534 & 58.829 \\
5 & 1.136 & 5.679 & 64.508 \\
\hline
\end{tabular}

Sumber : data diolah, 2019 
Dari tabel di atas terlihat bahwa hanya terdapat lima faktor yang terbentuk yang mewakili 20 atribut penelitian. Dari lima faktor tersebut memberikan sumbangan prosentase kumulatif varian sebesar 64,507 $\%$. Artinya bahwa lima faktor tersebut dapat menjelaskan semua atribut-atribut yang dipertimbangkan konsumen dalam memutuskan untuk menggunakan layanan Gofood.

Setelah diketahui jumlah faktor baru yang terbentuk berdasarkan tabel total variance explained, dari 20 atribut yang diteliti terdapat lima faktor baru yang terbentuk yang mewakili atribut-atribut tersebut, jumlah tersebut adalah jumlah yang optimal. Pada penelitian ini rotasi dilakukan dengan menggunakan metode varimax (bagian dari orthogonal). Pada tabel Rotated Component Matrix di bawah ini menunjukkan distribusi 20 atribut pada lima faktor baru yang terbentuk. Angka-angka pada tabel tersebut adalah factor loading, yang menunjukkan besar korelasi antara satu atribut dengan faktor baru yang terbentuk. Proses penentuan atribut tertentu akan dimasukkan ke faktor yang mana, hal ini dilakukan dengan melihat nilai factor loading. Atribut tertentu tersebut akan dimasukkan ke faktor tertentu jika nilai factor loading pada faktor tertentu tersebut menunjukkan nilai tertinggi di antara nilai factor loading atribut tersebut terhadap faktor baru yang terbentuk yang lain.

Pada tahapan rotasi, terdapat aturan angka pembatas (cut off point) agar sebuah atribut bisa secara nyata termasuk sebuah faktor. Angka pembatas tersebut nilainya sebesar 0,55 . Apabila sebuah atribut tertentu memiliki nilai factor loading tertinggi pada faktor tertentu di antara faktor lain tetapi nilai factor loading tersebut kurang dari 0,55 (di bawah nilai cut off point), maka atribut tersebut tidak bisa dimasukkan ke dalam faktor yang terbentuk, atau dengan kata lain atribut tertentu tersebut tidak dimasukkan ke dalam faktor manapun dan harus dikeluarkan dari model.

Berdasarkan tabel Rotated Component Matrix di atas, dapat dilakukan pengelompokan atribut-atribut, masuk ke dalam faktor yang mana setiap atribut yang dimasukkan dalam penelitian. Hal ini dilakukan berdasarkan nilai factor loading-nya. Terdapat tujuh atribut dalam penelitian ini harus dikeluarkan dari model. Hal ini disebabkan karena nilai factor loading-nya kurang dari 0,55 (di bawah nilai cut off point). Berikut hasil pengelompokan atribut-atribut dalam penelitian ini setelah dilakukan rotasi disajikan pada Tabel 3 di bawah ini.

Tabel 3. Pengelompokan Atribut-Atribut pada Faktor yang Terbentuk Berdasarkan Nilai Factor Loading Setelah Rotasi

\begin{tabular}{cccccc}
\hline \multirow{2}{*}{ Atribut } & $\mathbf{5}$ & $\mathbf{2}$ & $\mathbf{3}$ & $\mathbf{4}$ & $\mathbf{5}$ \\
\hline Pertanyaan18 & .755 & & & & \\
Pertanyaan15 & .738 & & & & \\
Pertanyaan17 & .688 & & & & \\
Pertanyaan14 & .687 & & & & \\
Pertanyaan13 & & .783 & & & \\
Pertanyaan11 & & .750 & & & \\
Pertanyaan8 & & .605 & & & \\
Pertanyaan19 & & .567 & & & \\
Pertanyaan2 & & & .771 & & \\
Pertanyaan1 & & & .711 & & \\
Pertanyaan5 & & & .565 & & \\
Pertanyaan7 & & & & & \\
Pertanyaan12 & & & & & \\
Pertanyaan20 & & & & & \\
Pertanyaan16 & & & & \\
Pertanyaan3 & .744 & & & \\
Pertanyaan6 & .658 & & & \\
\hline
\end{tabular}

Sumber : Data diolah, 2019

Berdasarkan hasil analisis dalam penelitian ini, 20 atribut, dengan proses factoring bisa direduksi menjadi lima faktor. Penentuan jumlah faktor yang terbentuk ini berdasarkan pasa tabel total variance explained. Pada tabel tersebut jumlah faktor yang menunjukkan nilai eigenvalue $>1$ hanya terdapat lima faktor. Lima faktor yang terbentuk tersebut memberikan sumbangan prosentase kumulatif varians sebesar 64,508\%. Hal ini berarti bahwa lima faktor yang terbentuk tersebut dapat menjelaskan atribut-atribut yang menjadi persepsi konsumen dalam menggunakan layanan platform Go-food sebesar $64,508 \%$, sedangkan sisanya 35,492 $\%$ dijelaskan oleh atribut lain yang tidak masuk dalam model ini. Berikut lima faktor yang terbentuk dari penelitian ini.

1) Faktor 1 : terdiri dari atribut pesanan online mudah dipahami, pesan konfirmasi pesanan cepat, loading time yang cepat, pemrosesan pesanan bebas kesalahan, pengiriman pesanan cepat, dan kebijakan retur pesanan dinamakan faktor kinerja layanan.

2) Faktor 2 : terdiri dari atribut tawaran 
beragam produk mitra, tawaran produk promosi, rekomendasi produk lain yang unik, dan dukungan berbagai cara pembayaran dinamakan faktor kemudahan akses.

3) Faktor 3 : terdiri dari atribut ketersediaan chatroom online, ketersediaan gambar produk, dan interaksi komunikasi yang bagus dinamakan faktor interaksi,

4) Faktor 4 : terdiri dari atribut informasi ketersediaan produk dan informasi yang disediakan akurat dinamakan faktor informasi.

5) Faktor 5 : terdiri dari atribut informasi pribadi dan informasi akun yang aman dinamakan faktor keamanan.

Berdasarkan hasil analisis faktor, atributatribut tersebut tereduksi menjadi lima faktor, di mana lima faktor yang terbentuk tersebut dapat menjelaskan atribut- atribut membentuk persepsi konsumen dan kemudian manjadi pertimbangan dalam memutuskan untuk menggunakan Go-Food sebesar $64,508 \%$, sedangkan sisanya 35,492 $\%$ dijelaskan oleh atribut lain yang tidak masuk dalam model ini. Adapun lima faktor baru yang terbentuk tersebut adalah meliputi kinerja layanan, kemudahan akses, interaksi, informasi, dan keamanan. Besarnya peranan masing-masing faktor dapat dilihat dari besarnya nilai prosentase varian yang ada (tabel 2).

\section{Kinerja layanan}

Faktor kinerja layanan terdiri dari atribut pesanan online mudah dipahami, pesan konfirmasi pesanan cepat, loading time yang cepat, pemrosesan pesanan bebas kesalahan, pengiriman pesanan cepat, dan kebijakan retur pesanan. Penjualan ritel yang dilakukan secara online akan selalu berupaya untuk menciptakan e-satisfaction. Produk jasa yang ditawarkan secara online tentu saja memiliki spsefikiasi yang berbeda dibandingkan dengan penjualan produk offline terutama dalam membangun kepercayaan konsumen (Suryaningsih, 2019:121). Platform go-food memberikan kemudahan bagi konsumen dalam memesan makanan atau minuman yang diinginkan. Go-Food selalu melakukan update patch setiap kali ada fitur terbaru yang ditawarkan, sehingga beberapa jenis mitra dikelompokkan menjadi beragam katergori yaitu: new this week, promotions, near me, best sellers, delivery promo, 24 hours, budget meal, healthy food, dan mostloved (Ariyanti, 2018). Kategori yang terdapat dalam platform ini sangat mengakomodir dari kebutuhan pelanggan. Setelah pelanggan selesai melakukan pemesanan maka, berikutnya tunggu sampai sistem GO-JEK mencarikan driver untuk Anda, sehingga proses ini termasuk menjadi atribut loading time, semakin cepat loading time semakin cepat pesanan terkonfirmasi. Konfirmasi pesanan akan dilakukan oleh driver go-jek baik melalui telepon dana tau melalui chatroom yang ada pada halaman platform gojek. Beberapa tahapan ini dilakukan untuk menekan pemrosesan kesalah pesanan yang dilakukanoleh driver sehingga retur pesanan dapat dihindari.

\section{Kemudahan akses}

Faktor 2 terdiri dari atribut tawaran beragam produk mitra, tawaran produk promosi, rekomendasi produk lain yang unik, dan dukungan berbagai cara pembayaran. Tawaran yang beragam dalam platform gofood dapat terlihat melalui kategori layanan "This Week". Kategori ini menampilkan merchant atau mitra yang baru saja bergabung dalam layanan Go-Food. Namun demikian, untuk urutan merchant atau mitra dalam pilihan didasarkan pada jarak terdekat dengan lokasi pelanggan go-food. Informasi pada kategori layanan ini sangat lengkap, di antaranya jarak antara pelanggan dengan mitra, nama mitra, alamat lengkap mitra, status buka atau tutupnya mitra, hingga jam operasional mitra.

Kategori layanan ini sangat membantu pelanggan karena memuat informasi merchant atau mitra terbaru yang berada di sekitar pelanggan. Oleh karenanya, pelanggan tidak hanya dapat menikmati makanan 'kekinian' ,akan tetapi mendapatkan update informasi kuliner terbaru. Tawaran produk promosi tersedia dalam kategori layanan "Promotions".

Go-Food memberikan beberapa promo menarik, berupa special price untuk pelanggan yang membeli via Go-Food, atau promo free delivery charge. Akan tetapi, pelanggan dapat menikmati promo delivery charge, kamu jika pelanggan melakukan order dengan aplikasi Go-Food. Rekomendasi produk lain yang unik tersedia pada kategori layanan Budget Meal, 
Healthy Food, dan Most Loved. Budget Meal kategori layanan ini memberikan penawaran pilihan menu makanan yang sesuai keinginan, mulai dari yang sangat murah, terdekat, ataupun tawaran promo lainnya. Selain itu, kategori layanan "Healthy Food" menawarkan makanan sehat berupayoghurt, jus sehat, salad. Bentuk promosi lain yang ditawarkan adalah "Most Loved", yaitu kategori layanan yang menampilkan restoran yang banyak ditandai sebagai favorit oleh pengguna layanan Go-Food. Konsep ini seperti best seller, namun sistem pengurutan mitranya berdasarkan jumlah pelanggan yang memasukkan mitra tersebut ke dalam list favorit mereka.

Dukungan berbagai cara pembayaran dilakukan melalui kategori layanan Pengguna Go-Food antara lain: tunai dan menggunakan vitual money dengan nama go-pay. Go-Jek pada platform go-food menyediakan sistem pembayaran dengan menggunakan cash atau uang tunai. Kekurangan dari pembayaran tunai adalah pelanggan tidak dapat menikmati promofree delivery charge, namun kelebihannya, pelanggan tidak perlu upaya mengisi Go-Pay. Metode pembayaran uang virtual atau elektronik Go-Pay ini lebih praktis. Go-Pay banyak promo menarik yang ditawarkan untuk memotivasi konsumen menggunakan sistem pembayaran tersebut.

\section{Interaksi}

Faktor 3 terdiri dari atribut ketersediaan chatroom online, ketersediaan gambar produk, dan interaksi komunikasi yang bagus. Ketersediaan chatroom online yaitu fitur inapp chat yang memudahkan pelanggan dan driver untuk berkomunikasi. Pertanyaanpertanyaan mengenai pesanan makanan pelanggan menjadi lebih mudah dan praktis, sebagai contoh (https://www.gojek.com/blog/go-food-inijie/ ,2019):

"Pesanan sesuai aplikasi ya"

"Ayam bakar pahanya habis, mau ganti apa kak?"

"Antrian martabaknya masih lama, kakak mau tunggu?"

"Saya sudah sampai di depan rumah pagar hitam yang ada pohon palem"

Informasi tersebut seakan sederhana, namun sangat penting bagi driver untuk disampaikan kepada pelanggan. Tujuan menu layanan ini adalah agar pelanggan cepat merespon sehingga dapat mempercepat proses pemesanan makanan di restoran.

Dengan demikian, penambahan fitur in-app chat ini menjadi sebuah solusi tepat baik bagi driver maupun bagi pelanggan. Fitur in-app chat ini tersedia otomatis setelah pelanggan memesan layanan go-food dibawah halaman utama go-food atau di bagian halaman pesanan, dan juga tidak perlu keluar dari aplikasi untuk menghubungi driver. Melalui fitur ini tentu dapat memperlancar interaksi komunikasi antara driver dengan pelanggan dan atau sebaliknya (Rahman, 2017:8).

Ketersediaan gambar produk pada ritail online merupakan suatu hal yang sangat penting dalam memengaruhi konsumen untuk membeli (Rahmat, et al, 2017). Berdasarkan survey internal go-jek, transaksi dapat meningkat sebesar $22.85 \%$, selain itu, $70.4 \%$ menu ditambahkan foto memiliki angka pemesanan yang lebih tinggi. Restoran/mitra go-jek yang memasang foto untuk menumenunya pada aplikasi go-food, mendapatkan respon yang sangat baik terkait dengan penjualan produknya. Kondisi tersebut membuat go-jek memiliki tanggung jawab moral membantu para mitranya untuk memanfaatkan peluang sehingga tim go-jek bekerja sama dengan food photographer, Jiewa Vieri, pendiri Inijie Studio memberikan workshop tentang cara membuat foto makanan serta praktek mengenai food photography agar lebih memiliki nilai jual (https://www.gojek.com/blog/go-food-inijie/, 2019).

Interaksi komunikasi menjadi sangat penting dalam layanan platform go-food (Novilah, 2017). Go-food merupakan layanan yang beresiko namun memiliki banyak poin yaitu 3 poin sekali order, hal ini dikarenakan seorang pengemudi go-jek harus menyediakan uang terlebih dahulu untuk rderan Go- food untuk membelikan pesanan dari calon pelanggan yang memesan dengan jumlah nominal sesuai dengan sistem informasi dari daftar menu. Setelah mendapatkan order dari sistem informasi kemudian pengemudi Go-jek langsung menghubungi calon pelanggan dengan tujuan memastikan restoran mana yang akan di belikan menu tesebut dan sebelum dibayarkan ke kasir harus 
menghubungi pelanggan dengan tujuan memastikan apakah menu sudah terpenuhi semuanya dan memastikan harganya sesuai dengan estimasi harga yang diberikan oleh sistem informasi. Setelah di bayar kemudian seorang pengemudi Go-jek menuju ke lokasi pelanggan untuk menerima menu makanan/minuman dan uang pembayaran dan ongkos jasa go-jek di bayarkan di tempat tujuan lokasi pelanggan jika tunai dan mendapatkan penggantian dari aplikasi jika menggunakan go-pay.

\section{Informasi}

Faktor 4 : terdiri dari atribut informasi ketersediaan produk dan informasi yang disediakan akurat. Pentingnya Informasi menu dan informasi mitra atau restoran menjadi pertimbangan utama bagi konsumen pengguna layanan aplikasi online. Oleh sebab itu, go-jek memberika satu fasilitas tambahan sehingga pengguna layanan go-food dapat memberi review (penilaian) kepada mitra penjual. Fitur terbaru ini merupakan langkah awal agar Go-food tidak sekedar layanan pesan antar makan, namun demikian menjadi sebagai sumber informasi dan referensi penilaian kuliner. Dengan adanya penilaian ini, diharapkan bisa menjadi referensi para pecinta kuliner untuk membeli makanan yang berkualitas dari segi rasa maupun layanan melalui platform go-food. Disisi lain, sistem penilaian ini dapat membantu perkembangan mitra yang baru merintis usaha. Hal ini bertujuan agar penjual baru mampu belajar agar supaya bisa dipercaya oleh pelanggan. Go-food melakukan strategi personalisasi bagi setiap pengguna, sehingga pengguna akan mendapatkan rekomendasi yang berbedabeda berdasarkan jarak restoran terdekat, hasil pencarian pengguna, sampai dengan promo atau kategori. Selain menganalisis kebiasaan makan para pengguna Go-food, Gojek dalam, hal ini mengembangkan kecerdasan buatan (artificial intellegence) untuk menawarkan rekomendasi kuliner kepada pelanggan yang didasarkan pada lokasi dan pencarian kuliner di aplikasi Go-jek. Data tersebut juga dapat digunakan mitra penjual agar selalu melakukan inovasi menghadapi persaingan bisnis kuliner (CNN Indonesia, 2019).

\section{Keamanan}

Faktor 5 : terdiri dari atribut informasi pribadi dan informasi akun yang aman. Pada setiap penggunaan akun online keamanan menjadi factor kunci dalam menjaga kepercayaan konsumen. Dengan adanya virtual money pembayaran pada platform go-food yaitu yang dikenal dengan akun go-pay. Kepemilikan akun go-pay merupakan suatu bentuk kepercayaan konsumen pada penyedia jasa berupa uang dan informasi pelanggan. Jika pengguna menyetujui pengumpulan data, pemanfaatan, dan penyerahan data pengguna yang disampaikan pada pada aplikasin go-jek dan/atau mitra platform resmi go-jek dijamin kerahasiaannya melalui syarat dan ketentuan yang diberikan go-jek dan disetujui oleh pengguna pada laman https://www.GOJEK.com/privacy-policy ("kebijakan privasi kami"). Dilain pihak, untuk layanan informasi lainnya disediakan melalui Call Center GoFood yaitu Call Center GoFood. 021 - 50251110 dan Email Customer Service GoFood. customerservice@go-jek.com.

\section{Kesimpulan}

Berdasarkan hasil analisis data dan pembahasan pada bab sebelumnya, sesuai dengan tujuan dilakukannya penelitian ini, maka hasil penelitian ini dapat diambil kesimpulan bahwa hasil analisis faktor terhadap 20 atribut yang dimasukkan dalam penelitian ini adalah terbentuk lima faktor yang mewakili atribut-atribut dalam Internet Retail Service Quality (IRSQ) tersebut yang membentuk persepsi konsumen dalam menggunakan layanan aplikasi go-jek melalui platform go-food.. Adapun faktor-faktor yang terbentuk tersebut adalah meliputi meliputi kinerja layanan, kemudahan akses, interaksi, informasi, dan keamanan.

Faktor yang paling dominan adalah adalah kinerja layanan yang terdiri dari atribut pesanan online mudah dipahami, pesan konfirmasi pesanan cepat, loading time yang cepat, pemrosesan pesanan bebas kesalahan, pengiriman pesanan cepat, dan kebijakan retur pesanan. Faktor kedua adalah kemudahan akses yang terdiri dari atribut tawaran beragam produk mitra, tawaran produk promosi, rekomendasi produk lain 
yang unik, dan dukungan berbagai cara pembayaran. Faktor ketiga adalah interaksi yang terdiri dari atribut ketersediaan chatroom online, ketersediaan gambar produk, dan interaksi komunikasi. Faktor keempat adalah informasi yang terdiri dari atribut informasi ketersediaan produk dan informasi yang disediakan akurat, sedangkan faktor kelima yaitu keamanan yang terdiri dari atribut informasi pribadi dan informasi akun yang aman.

\section{Saran}

Bagi pihak PT. Go-Jek Indonesia, berdasarkan hasil penelitian maka saran yang diberikan yaitu untuk terus meningkatkan kualitas pelayanan, dan mempertahankan profesionalitas yang bertujuan untu terus membangun kepercayaan serta kepuasan konsumen dalam menggunakan aplikasi go-jek melalui platform go-food. Bagi perusahaan mitra kerja Go-Food diharapkan dapat mempertahankan serta meningkatkan kualitas produk, inovasi tehnik promosi, dan mempelajari dan memahami selera konsumen.

Kesempatan bagi peneliti lain yang ingin menyempurnakan dan melanjutkan penelitian ini masih terbuka lebar. Disarankan kepada peneliti lain yang ingin menyempurnakan dan melanjutkan penelitian ini untuk memperbanyak atribut agar memberikan nilai kumulatif varian lebih tinggi. Hasil analisis factor juga dapat dilanjutkan dan dikombinasikan dengan alat analisis lainnya seperti regresi linier berganda sehingga dapat diketahui besaran koefisien pengaruh dari masing-masing factor yang terbentuk oleh hasil Exploratory Factor Analysis (EFA).

\section{Daftar Referensi}

Ardyanto, Denni. 2015. Pengaruh Kemudahan Dan Kepercayaan Menggunakan E-Commerce Terhadap Keputusan Pembelian Online (Survei Pada Konsumen www.petersaysdenim.com). Jurnal Administrasi Bisnis. Vol. 22, No 1.

Ariyanti, Fiki. 2018. Cara Pesan Go Food dari Ponsel Kamu Biar Dapat Makanan Lebih Cepat dan Mudah. https://www.cermati.com/artikel/.

Diakses 6 Juni 2019

Bayu., Dimas Jarot. 2018. Ini Lima Layanan Go-Jek yang Paling Banyak Digunakan Konsumen. https://katadata.co.id/berita/2018/03/22/. Diakses 15 Juni 2019.

Brady, M.K. and J.J. Cronin, Jr. 2001. Some New Thought on Conceptualizing Perceived Service Quality: A Hierarchical Approach. Journal of Marketing. Vol. 65. Pp. 34-39.

CNN Indonesia. 2019. GoFood Jajal Fitur Baru, 'Review' Makanan dan Layanan Penjual. https://www.cnnindonesia.com/teknologi/20 190107194024-185-359116/. Diakses 3 Juli 2019.

Ghozali, Imam. 2005. Aplikasi Analisis Multivariate dengan SPSS. Semarang Badan Penerbit Fakultas Ekonomi Universitas Diponegoro.

http://m.okezone.com, 2018, diakses 25 Mei 2019. https://www.gojek.com/ diakses 25 Mei 2019.

https://www.gojek.com/blog/go-food-inijie/ , Diakses 10 Juli 2019

Janda, S., P.J. Trocchia, and K.P. Gwinner. 2002. Consumer perceptions of Internet Retail Service Quality. International Journal of Service Industry Management. Vol. 13. No. 5. Pp. 412431.

Kotler, Philip, 2000. Marketing Management. Edisi Milenium, Prentice Hall. Inc New Jersey.

Mujiyana, dan Ingge Elissa. 2013. Analisis FaktorFaktor Yang Mempengaruhi Keputusan Pembelian Via Internet Pada Toko Online. Jurnal Teknik Industri, Vol.8. No. 3. Pp. 1143153.

Novianty, Dythia., dan Muslimin Trisyuliono. 2019. Dua Layanan Go-Jek Ini Diklaim Paling Banyak Digunakan di Indonesia. https://www.suara.com/tekno/2019/04/ 12/082143/. Diakses 28 Juni 2019.

Novilah. 2017. Aktivitas Komunikasi Customer Relations Dalam Layanan Pengemudi Gojek Srikandi Terhadap Pengguna Jasa. Jurnal Visi Komunikasi. Volume 16. No. 01. Pp. 131 - 150.

Nurbayti. 2019. Tren Pengguna Aplikasi Go-Food Di Era Digital. Jurnal Komunikasi, Masyarakat Dan Keamanan. Vol.1 no. 1.

Rahman, Taufiqur. 2017. Conviviality and New Imagined Community in the Cyberspace. Komunikasi, Religi dan Budaya" dan "Komunikasi Berkemajuan". Buku Bunga Rampai. Asosiasi Pendidikan Ilmu Komunikasi Perguruan Tinggi Muhammadiyah (APIK PTM) 
bekerjasama dengan Program Studi Ilmu Komunikasi Universitas Muhammadiyah Ponorogo dan Buku Litera Yogyakarta.

Rahmat, Sulfiana., Nasri Hamang, dan Nurhakki. 2017. Pengaruh Online Shop Terhadap Minat Beli Mahasiswa STAIN Parepare. http://ejurnal.stainparepare.ac.id/in dex.php/komunida/article. Pp. 22-45.

Santoso, Singgih. 2001. Riset Pemasaran: Konsep dan aplikasi dengan SPSS.Jakarta: PT Elex Media Komputindo.

Simamora, Bilson. 2005. Analisis Multivariat Pemasaran. Jakarta: PT Gramedia Purtaka Utama.

Sugiyono. 2015. Metode Penelitian Kuantitatif Kualitatif dan R\&D. Bandung. Alfabeta.

Suryaningsih, Ika Barokah. 2019. Perilaku Konsumen Pasar Bisnis: Kajian Teori \& Empiris. Dream Litera Buana Malang

Tjiptono, Fandy. 2014. Pemasaran Jasa-Prinsip, Penerapan, dan Penelitian. Edisi 1. Yogyakarta: Andi

Verina, Eunike., Edy Yulianto., dan Wasis A. Latief. 2014. Faktor-Faktor Yang Mempengaruhi Keputusan Pembelian Pada Toko Fashion Di Jejaring Sosial Facebook (Survei pada Konsumen Toko Fashion di Jejaring Sosial Facebook yang berlokasi di Indonesia). Jurnal Administrasi Bisnis (JAB). Vol. 10 No. 1.

Wibisono, Totok., Nuria Universari, dan Adijati Utaminingsih. 2017. Faktor-Faktor Yang Mempengaruhi Pengguna Transportasi Gojek Di Kota Semarang: Sebuah Analisis Kualitatif. Jurnal Dinamika Sosial Budaya (JDSB). Vol. 19. No.2.

www.topbrand.com, 2018, diakses 25 Mei 2019. 